\title{
The Influence of Taxation Knowledge, Usability, and Penalty of Tax Amnesty on Public Perception in the Implementation of Tax Amnesty Policy
}

\author{
Zulhawati \\ Faculty of Business and Information Technology \\ Universitas Teknologi Yogyakarta \\ Kampus Jombor, Yogyakarta, Indonesia \\ zulhawati@uty.ac.id
}

\begin{abstract}
The purpose of this study is to determine the influence of taxation knowledge, usability, and penalty of tax amnesty on public perception in the implementation of tax amnesty policy in Kademangan Village, South Tangerang, Indonesia. The sampling was done by using accidental sampling method. The research data were collected from those paying taxes and registered as taxpayers in Kademangan Village, South Tangerang, Indonesia. The samples consist of 100 respondents, where the sampling technique applied is multiple linear in SPSS ver. 22. The results of this study confirm that partially measured variables of taxation knowledge-i.e. knowledge on tax function, tax amnesty policy, tax amnesty application procedures, and tax amnesty rates-on the public perception in the implementation of tax amnesty policy show positive and significant impacts. The variables of usability as measured by the effectiveness, usability, and satisfaction degree of public perception in the application of tax amnesty policy have positive and significant impacts. Variable of tax amnesty penalty is measured by the administrative sanctions imposed severely as a means to educate the taxpayers. Tax penalties, imposed without tolerance and negotiation, have positive and significant impact on the public perception in the implementation of tax amnesty policy. The taxation knowledge, usability, and penalty of tax amnesty simultaneously have positive and significant effect on public perception in the implementation of tax amnesty policy.
\end{abstract}

Keywords: Perception; Tax amnesty penalty; Taxation knowledge; Usability.

\section{Introduction}

Indonesia is a developing country whose development is planned according to the needs of its people, bearing more specific functions in the political, economic, social, cultural, and security defense sectors. In order to finance the development and run those functions, the government needs a large number of funds. The sources of state revenues come from various sectors, both internal and external sectors. One source from internal sector is the tax, while one of external revenue sources is foreign loan. As an effort to reduce dependence on external revenue sources, the government is striving to maximize the state revenues, especially in tax sector. Taxes are citizens' contributions to the treasury fund under the Law that can be imposed by not receiving reciprocal service directly, for forfeiting general expenses [1]. In the structure of revenues, tax revenues are the main source to fund government administration and national development. The role of tax revenue on the state's entire income from year to year has been increasing. This function is very important for the country; therefore, the Directorate General of Taxation (DJP), a government agency under the Ministry of Finance of Indonesia, acting as the administrator of the taxation system in Indonesia, tries to improve tax revenue through tax reform, aiming to set the tax system to be able to have a simplification including the tax 
rate, non-taxable income, and the tax collection system. This is stated in Law No. 36 of 2008 as the fourth amendment of Law No. 7 of 1983 on income tax. Law No. 36 of 2008 was enacted on September 23, 2008 and came into force since January 1, 2009. The ratification of Law No. 38 of 2007 on "General Provisions and Tax Procedures", mentions that taxpayer shall be an individual or corporate, including taxpayers, tax with holders, and tax collectors who have tax rights and obligations in accordance with the provisions of tax legislation [2]. Public reaction can be seen on the willingness of taxpayers to pay their taxes. Willingness to pay taxes is the number of value that is cooperatively contributed by a person (who has been determined by regulation) which is used to finance public expenditure of the state, and he/she does not receive contributions directly [3]. This becomes crucial because it affects the amount of state revenues.

The efforts to maximize tax revenue cannot simply rely on the role of Directorate General of Taxation and tax officials, but also on the active role of taxpayers. Changes in the taxation system from the Official Assessment into Self-Assessment, gives full trust to the taxpayers to calculate, deposit, and report the tax payable by themselves in accordance with the provisions of the applicable tax legislation; thereby, the determination of the amount of tax payable is on the taxpayers themselves [4]. This means that taxpayer is required to actively fulfill the tax obligations, ranging from registering, filling the tax return (SPT) honestly and properly, and paying off the tax payable [5]. The phenomenon occurring today is that the number of individual taxpayers from year to year is increasing, but there is an obstacle that can hinder the efforts to increase the tax ratio, called tax compliance of tax to GDP (tax ratio), it also can be seen that there was impairment ratio in 2014 to 2015, from an average of $12 \%$ to $11 \%$ (see Table 1 and Figure 1). This ratio was obviously still relatively low, compared to the world average or OECD countries (both around 14\%); this led Indonesia still in a state of under taxing.

Table 1. State Tax Revenue Target in 2011-2015 (in Trillion Rupiah)

\begin{tabular}{|c|c|c|c|}
\hline Year & Target & Revenue & Percentage \\
\hline 2011 & 878.70 & 872.60 & $99.31 \%$ \\
\hline 2012 & 885.00 & 835.20 & $94.31 \%$ \\
\hline 2013 & 995.20 & 920.00 & $92.44 \%$ \\
\hline 2014 & $1,066.00$ & 976.20 & $91.58 \%$ \\
\hline 2015 & $1,294.00$ & $1,055.00$ & $81.53 \%$ \\
\hline
\end{tabular}

Source: www.kompasiana.com 


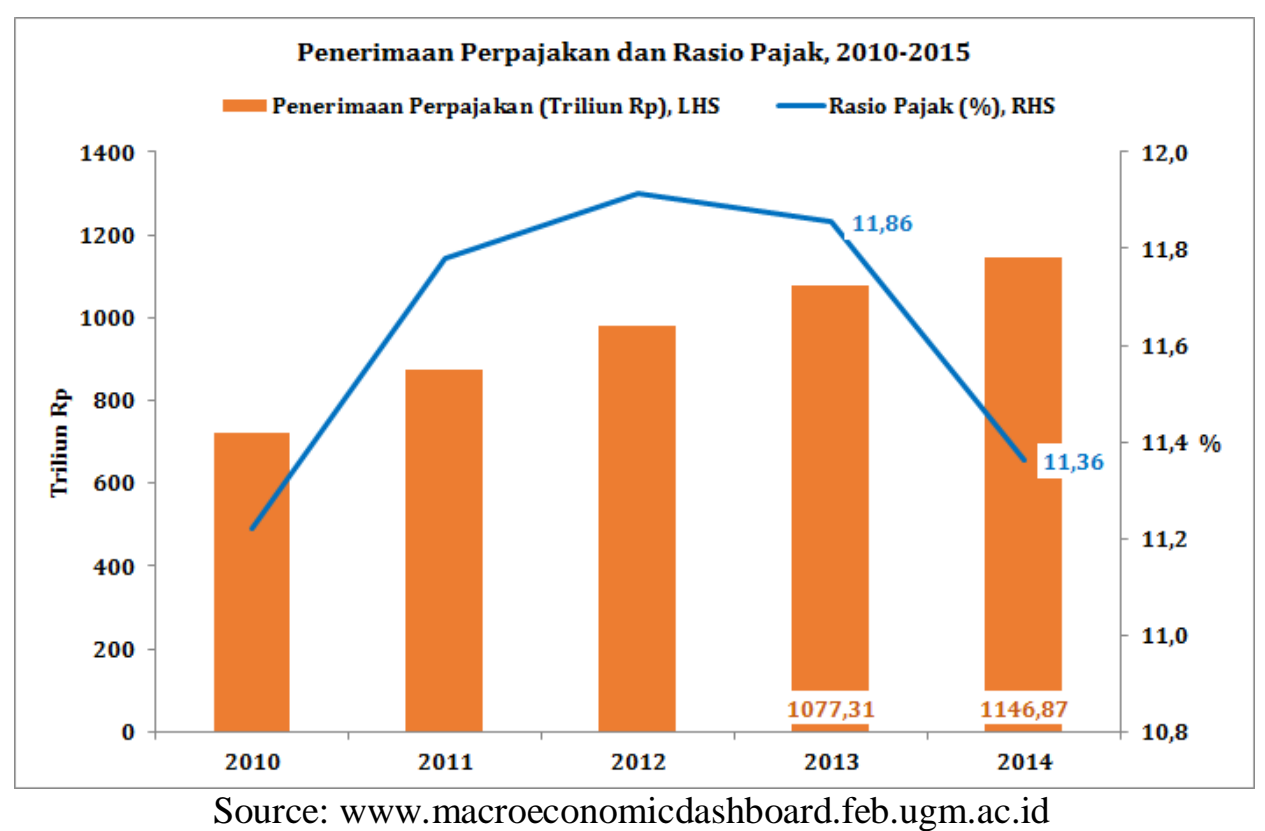

Figure 1. Tax Revenue and Tax Ratio in 2010-2015

Another case occurring in the taxation world recently is that taxpayers still have perception that tax is a kind of charge instead of a manifestation of their participation, this is because they have not seen the real impact of the tax for the country and the society. This makes the public and taxpayers worried to pay taxes. This condition can affect tax compliance because taxpayers do not want the taxes that have been paid be abused by the tax authorities. Therefore, some citizens and taxpayers are evading taxes. To encourage the fulfillment of tax obligations voluntarily, and raise the contribution of state revenues from taxpayers, the government has established tax amnesty under the amnesty program offered by the government to taxpayers. Tax amnesty came into force on July 18, 2016 in accordance with Law No. 11 of 2016 on the Tax Amnesty [6]. Tax amnesty aims to increase tax revenues in short term, raise the number of taxpayers, integrate informal sectors into the economic system, utilize the unused funds, and apply more sanctions as the initial step of the new regime policy. Tax Amnesty happens to be one of the government policies targeting individual taxpayers, corporate taxpayers, taxpayers engaged in the micro, small, and medium enterprises (SMEs) and individuals or entities that have not become a taxpayer. However, the real phenomenon occurring in public is that the perception of people assuming that every citizen does not have to pay taxes. The misunderstanding arose because the government strategy conveying a message about tax amnesty policy to the public is quite weak; thus leads to misunderstanding of Indonesian against the policy.

A study by Ritsema, et al. in [7] shows that the tax amnesty program conducted in the United States has a positive impact on the level of tax compliance and state revenue. Therefore, with the successful implementation of this policy in the United States, Indonesia adopted such policy with the same name in 1984. Later in 2008, the name tax amnesty changed into sunset policy, and in 2016 Indonesia once again applied the tax amnesty policy. Meanwhile the findings of Luitel and Sobel in [8] show that the tax amnesty did not have a significant effect, because often the program run in previous years reduced the interests of taxpayers due to the existence of tax amnesty. Based on some phenomena and the results of studies that have been done on tax amnesty program on the society, the tax amnesty policy is a policy that burdens the middle class people having to pay a ransom rates, when it supposed to target groups of conglomerates who have more assets, and particularly for low class people granted or inherited, and not able to pay taxes 
on the grants. Moreover, the advantage is not proportional to the amount of taxes paid by the taxpayers as well as the sanction if they do not follow the tax amnesty, which is too burdensome for the public. As the result, people still feel confused whether to participate or not in the tax amnesty program.

Based on the previous discussion, this paper presents the influence of knowledge, usability, and sanction of tax amnesty towards public perception on the implementation of tax amnesty program. The formulation of the problem in this study is as follows:

a. Does the taxation knowledge influence public perception on the implementation of tax amnesty?

b. Does the usability influence public perception on the implementation of tax amnesty?

c. Does the tax penalty influence public perception on the implementation of tax amnesty?

d. Do the tax knowledge, usability and tax penalty of tax amnesty influence public perception on the implementation of tax amnesty?

The rest of this paper is organized as follow: Section 2 describes the notions of tax and its components. Section 3 describes the hypotheses development and proposed research method. Section 4 presents obtained results and following by discussion. Finally, the conclusion of this work is described in Section 5.

\section{Rudimentary}

This section presents related studies of the definition of tax, taxation knowledge, usability, penalty and perception on the implementation of tax amnesty.

\subsection{Tax}

Tax has different definitions depending on the viewpoint expressed by the experts. Nevertheless, these definitions basically have the same goal of defining the tax to make it more easily understood. Tax, according to Article 1 Paragraph 1 of Law No. 6 of 1983 as amended by Law No. 28 of 2007 [9] on General Provisions and Tax Procedures, is the payable mandatory contribution to the state of individuals or entities that is enforceable under the Law, by not receiving the reciprocal impact directly, for it is used for the purposes of the state intended for the maximum prosperity of people. According to Mardiasmo in 10], tax is the contribution of a citizen to the state treasury under the law that can be imposed by not receiving reciprocal service directly for being used to pay for general expenses. Soemahamidjaja [11] in his dissertation entitled "Tax Based on the Principle of Mutual-Help (Pajak Berdasarkan Azas Gotong Royong)", published by Padjadjaran University, Bandung, states that tax is a mandatory fee in the form of money or goods levied by the authorities based on the norms of law to recover production costs of collective goods and services to achieve common prosperity. In addition, according to Waluyo and Ilyas in [12], tax is the compulsory contribution to the state, (which can be imposed) owed by the tax payers under the regulation, by no longer earning achievement, that can instantly appointed, in which to finance public expenditures associated with the tasks of the state that administrates government. From these definitions, it can be concluded that the qualities engaged in the definition of tax are:

a. Contribution of the citizen to the state; who has the right to collect taxes is only the state. The contribution is in cash (not goods).

b. Taxes levied are under the laws and rules of conduct that are enforceable.

c. In the tax payment, individual contra-achievement cannot be indicated by the government.

d. Taxes are levied by the state, both central and local government.

e. Taxes are intended for government expenditures; whenever there is still a surplus of revenue, it is used to finance public investment. 
Tax has a considerable role in the life of the nation. Some of the tax functions according Mardiasmo in [10] are as follows:

a. Budgetary Function

Budgetary function is referred to as the main function of tax or fiscal function, which is a function where the tax is used as a tool for optimally inserting funds to the state treasury based on the tax laws and regulations applied.

b. Regulating Function

This function means that the tax can be used as an instrument to achieve certain goals.

Meanwhile, according to Mardiasmo in [10], tax can be classified into three groups, as follows:

a. Based on the Class

1) Direct Tax; is the tax charged to the taxpayer and cannot be charged or delegated to others, for example: Income Tax.

2) Indirect Tax; is the tax that can be ultimately charged or delegated to others, for example: Value Added Tax.

b. Based on the Feature

1) Subjective Tax; is the tax that stems from or is based on the subject, in the sense of concerning the state of being of the taxpayers, for example: Income Tax.

2) Objective Tax; is the tax that stems from the object regardless of the state of being the taxpayer, for example: Value Added Tax and Sales Tax on Luxury Goods.

c. Based on the Collecting Institutions

1) Central Tax; is the tax levied by the central government and used to finance the state household, for examples: Income Tax, Value Added Tax, Sales Tax on Luxury Goods and Stamp Duty.

2) Regional Tax; is the tax levied by local government and used to finance the regional household. Local tax consist of:

a) Provincial Tax, for example: Motor Vehicle Tax and Motor Vehicle Fuel Tax.

b) District/Municipal Tax, for example: Hotel Tax, Restaurant Tax and Entertainment Tax.

The tax collection in Indonesia applies some systems, according to Mardiasmo in [10] i.e.:

a. Official Assessment System: a collection system that gives authority to government (tax authority) to determine the amount of the tax payable of the taxpayer.

b. Self-Assessment System: a system of tax collection that authorizes the taxpayer to decide the amount of tax payable.

c. With Holding System: a system of taxation authorizing the third party (not the tax authority nor the taxpayer) to determine the amount of tax payable of the taxpayer.

Meanwhile, the principles of tax collection according to Mardiasmo in [10], consist of:

a. The Principle of Domicile (home residence): The state has right to tax the entire income of taxpayers residing in its territory, whether the income comes from inside and outside the country.

b. The Principle of Source: The state is entitled to impose tax on income derived from sources in its territory, regardless of the taxpayer's residence.

c. The Principle of Nationality: The taxation is based on the nationality or citizenship of the taxpayer.

From the definition above, there are two types of tax subjects, including: first, individual taxpayer, that is any person who has an income above Taxable Income (PKP) and is required to have a Taxpayer Identification Number (NPWP), and second, corporate taxpayer is a group of people and/or capitals as a unity, both those who do and not do business. 


\subsection{Tax Amnesty}

Based on Law No. 11 of 2016 [6] on Tax Amnesty, tax amnesty is the elimination of the tax payable, without tax administrative sanction and criminal sanction in the field of taxation, by uncovering assets and paying the ransom as stipulated in this law. According to the Minister of Finance Regulation (PMK) No. 118/PMK.03/2016 [13], tax amnesty is the elimination of tax payable without tax administrative sanction and criminal sanction in the field of taxation, by uncovering assets and paying the ransom as stipulated in Tax Amnesty Law. From both definitions of tax amnesty, it can be concluded that tax amnesty is an amnesty program granted by the government to taxpayers including the elimination of tax payable, the removal of tax administrative sanction, as well as the elimination of criminal sanction in the field of taxation on the property acquired in 2015 and previously that have not been reported in the tax return, by paying off all tax arrears and the ransom. The benefits or profits obtained by the taxpayer who follow the tax amnesty program include:

a. The elimination of tax payable that has not been issued as the tax assessment, non-penalization by tax administrative sanction, and non-subject to criminal sanction in the field of taxation for fiscal liability in the tax period, part of the tax year, and the tax year, until the end of the last tax year related to the fiscal liability of Income Tax (PPh), Value Added Tax (PPN), or Value Added Tax on Luxury Goods (PPnBM).

b. Elimination of the tax administrative sanction in the form of interest, or penalty, for tax liability in the tax period, part of the tax year and the tax year, until the end of the last tax year related to the tax liability of Income Tax (PPh), Value Added Tax (PPN), or Value Added Tax on Luxury Goods (PPnBM).

c. There is no tax audit, preliminary evidence examination and investigation of criminal offenses in the field of taxation on tax liability in the tax period, part of the tax year and the tax year, until the end of the last tax year related to the tax liability of Income Tax (PPh), Value Added Tax (PPN), or Value Added Tax on Luxury Goods (PPnBM).

d. Termination of tax audit, preliminary evidence examination and investigation of criminal offenses in the field of taxation, in case that the taxpayer is under tax audit, preliminary evidence examination, and investigation of criminal offenses in the field of taxation on tax liability, until the end of the last tax year related to the tax liability of Income Tax (PPh), Value Added Tax (PPN), or Value Added Tax on Luxury Goods (PPnBM).

Meanwhile, tariffs that have been imposed by the government through the Directorate General of Taxation for tax amnesty program are as follows:

a. Assets inside the country or abroad invested in Indonesia for 3 years.

1) The first three months: rate of $2 \%$

2) Four months until December 31, 2016: rate of 3\%

3) January 1, 2017 until March 31, 2017: rate of 5\%

b. Assets abroad and not diverted into the country.

1) The first three months: rate of $4 \%$

2) Four months until December 31, 2016: rate of $6 \%$

3) January 1, 2017 until March 31, 2017: the rate of 10\%

c. Taxpayers of Micro, Small and Medium Enterprises.

1) Revealing the value of assets of IDR 4.8 billion up to IDR 10 billion in the affidavit at the rate of $0.5 \%$

2) Revealing the value of assets of more than IDR 10 billion in the affidavit for the first month of the period until March 31, 2017 at the rate of 2\%. 


\subsection{Taxation Knowledge}

Knowledge is the result of human senses, or one's understanding of the object through his senses (eyes, nose, ears, and so on) [14]. Knowledge is something known to be associated with the learning process. This learning process is influenced by various factors such as motivation as the internal factor and available information tool as the external factor as well as socio-cultural circumstances [15]. The knowledge that a person has definitely comes from various sources. Here are the sources of knowledge of a person:

a. Belief based on tradition

b. Customs and religion

c. Five senses/experience

d. Mind

e. Individual intuition

In knowledge management, there are two main types of knowledge based on the explicitness:

a. Implicit Knowledge

Implicit knowledge is knowledge that is embedded in the form of a person's experience containing factors that are not real as personal beliefs, perspectives, and principles. Implicit knowledge often contains customs and culture that we do not even realize.

b. Explicit Knowledge

Explicit knowledge is knowledge that has been documented or stored in a tangible manifestation in the form of media or the like and has been articulated into a formal language and can relatively easy to be widely spread.

According to Notoatmodjo [14], there are several factors that can affect a person's knowledge, namely:

a. Education

Education is an attempt to develop personality and ability inside and outside the school that lasts a lifetime.

b. Media/Information Resources

As the communication tool, various forms of mass media such as television, radio, newspapers, magazines, internet, and so forth, have a major influence on the formation of opinions and beliefs of people.

b. Social, Cultural, and Economic Aspects

Habit and tradition are performed by people without reasoning the positive and negative sides.

c. Environment

Environment is everything existing around the individual, whether the physical, biological, and social environment.

d. Experience

Experience as a source of knowledge is a way to acquire the truth of knowledge by repeating the acquired knowledge in solving the problems encountered in the past.

Meanwhile, taxation knowledge is the knowledge regarding the concept of general provisions in the field of taxation. Types of taxes applicable in Indonesia ranging from tax subject, tax object, tax rates, calculation of taxes payable, registration of tax payable up to the process of fulfillment of tax reporting [16]. The concept of taxation knowledge, according to Rahayu in [17], is that the taxpayer must have:

a. Knowledge on general provisions and procedures of taxation.

b. Knowledge on the tax system in Indonesia.

c. Knowledge on the function of taxation. 
Rahayu in [17], provided the study of the importance of taxation knowledge for a taxpayer for it greatly affects the taxpayer's attitudes toward a fair taxation system. The advanced knowledge will generate the right attitude towards the obligation through the taxation system of a country that is considered fair. The increasing taxation knowledge of the citizens through both formal and non-formal tax education will have positive impact on the understanding of taxpayers in paying taxes. Intensive and continuous taxation counseling will increase understanding of the taxpayer to pay taxes as a form of national mutual assistance in raising funds for the government's financing and national development [15]. Based on the description above, it can be concluded that the taxation knowledge, especially knowledge of the tax amnesty, is the ability of taxpayers to learn the system of policies or programs made by the government in the field of taxation whether in terms of the purpose and objectives of the tax amnesty, the benefits of the tax that would be useful for their lives, the tax amnesty rates under the law or the sanction if not applying it. By the advanced knowledge of taxation, citizens will generate the right attitude towards the obligation to follow any development and take an active role in fulfilling the tax obligation. The instruments used to measure the knowledge of taxation consist of four indicators adopted from Imaniyah and Handayani in [18], which have been modified, namely:

a. Taxpayer's knowledge on tax functions.

b. Taxpayer's knowledge on tax amnesty policies.

c. Taxpayer's knowledge on the procedures of applying tax amnesty.

d. Taxpayer's knowledge on the tax rate of tax amnesty.

\subsection{Usability}

The usability, according to the International Organization for Standardization or abbreviated as ISO 9241-11, is the rate at which a product is used by specified users to achieve specified objectives effectively, efficiently, and satisfactorily within the scope of its utilization [19]. The usability is one of the factors used to measure the extent to which the user accepts the system. The usability is one of the factors used to measure the extent to which the user accepts the system. There are several factors determining a system to be "usable". Among the factors that are frequently used, there are six attributes of the usability, including:

a. Effectiveness: the accuracy and completeness by which the users achieve their goals.

b. Learn ability: easy to learn for new users.

c. Efficiency: steady state performance of expert users.

d. Memorability: uncomplicated system to use and memorable instructions.

e. Error: small error rate.

f. Subjective satisfaction: how the system is convenient to use.

Measuring the usability of a product can be done through the details as follows:

a. Learn ability

b. Efficiency

c. Memorability

d. Errors

e. Satisfaction

f. Presentation

g. Screen layouts

h. System capability

Based on the description above, it can be concluded that the usability of a product, in this case, the policy of tax amnesty is a way to measure the extent to which the program is beneficial for the taxpayers in terms of effectiveness, efficiency, and the level of satisfaction in following the program of tax amnesty that has been made by the government. By the factors that can measure the efficiency of the tax amnesty, it is 
expected that taxpayers have the willingness to join the program, so that they could see the advantage in the future. The instruments used to measure the usability consist of three indicators adopted from ISO 1998 which has been modified, namely:

1. Effectiveness: the accuracy and completeness by which the taxpayer achieve goals.

2. Efficiency: learning resources in accordance to the accuracy and completeness for the taxpayers.

3. Satisfaction: free from any discomfort and positive attitude in applying tax amnesty policy.

\subsection{Tax Penalty}

Penalty is an act in the form of punishment given to those who violate the rules. Regulations or legislations are signs for a person to do something about what should be and not be done. Penalty is so necessary that the rules or laws will not be violated. Tax penalty is a guarantee that the provisions of the legislation of taxation would be followed; in other words, the tax penalty is a deterrent for the taxpayer not violate the norms of taxation [20]. According to Resmi in [21], tax penalty is applied due to the violations of the tax legislation. Hence, in case of violation, the taxpayer is punished with an indication of tax policy and the tax laws. As we know, a policy including the imposition of sanctions could be used for two purposes, the first is to educate and the second is to punish. To educate means that those who are subject to sanctions would do better and know more about their rights and responsibilities, so that they will no longer make the same mistake. The second purpose is to punish, so that the condemned party will be wary and no longer make the same mistake [22]. Related to the tax amnesty policy, the sanctions provided for not using those facilities that have been granted by the state are as follows:

a. Taxpayers who do not meet the obligations of holding period, on the additional net assets is treated as income for the tax year 2016 and taxed and penalized in accordance with the provisions of the legislation in the taxation field.

b. Taxpayers who have followed the tax amnesty program, whose data on net assets less uncovered are found; thus such assets are treated as income at the time it is found and taxed according to the Income Tax Law, coupled with administrative sanction with an increase of $200 \%$ (two hundred percent) of the income tax that is not paid or underpaid.

c. Taxpayers who do not follow the tax amnesty program, whose data on net asset not reported are found; this asset is treated as income at the time it is found and taxed, as well as with administrative sanctions in accordance with applicable tax laws.

Views on tax penalty in the application of tax amnesty policy are measured by indicators [23] which have been modified, namely:

a. Administrative penalty is imposed for serious violators of tax rules.

b. Imposition of serious administrative penalty is a method of educating the taxpayers.

c. Tax sanctions should be imposed on violators of tax without tolerance.

d. Imposition of penalties for violations of the tax must not be negotiated.

Based on the description above, it can be concluded that the sanctions are approaches conducted by the tax authorities in order that the taxpayers will not commit any fraud in paying taxes. With such heavy administrative sanction given to the taxpayers who violate, the taxpayers are expected to have motivation to follow the policy on the application of this tax amnesty.

\subsection{Perception}

Perception is direct response or recognition of a person. According to Rakhmat in [24], perception is experience about objects, events, or relationships obtained by concluding information and interpreting the message. Meanwhile, according to Walgito in [25], 
perception is a process preceded by sensing, that is the stimulus process by an individual through sensory processes. However, the process does not merely stop, such stimulus is distributed and subsequently processed then becomes the process of perception. Another opinion comes from Leavitt in [26]. He stated that perception could be seen in a narrow sense, namely sight. It is how a person sees something. Whereas in the broad sense, it is a view or interpretation, i.e. how one views or interprets something. The process of perception cannot be separated from the sensing process, and it is prior to the process of perception. Perception can be summarized as a process of sensing. The stimulus received by an individual through the sensory organs is then interpreted, so that a person can give his view, understand and interpret the meaning of the stimulus received. The process of interpreting is commonly influenced by the experience and learning process of an individual. Mulyana in [27] outlined the human perception into two parts, namely:

a. Perception against an object (physical environment); external features, while the perception on people is responding to the outer and inner characteristics (feelings, motives, expectations, and so on). People will perceive you when you perceive them. In other words, human's perception is interactive.

b. Perception against humans; through physical symbols, while perceptions on people are processed through verbal and non-verbal symbols. People are more active than most objects, and they are more difficult to predict.

The factors that affect perceptions according to Rakhmat in [24] are as follows:

a. Functional Factors

Functional factors are derived from the needs, past experiences and other things included as the so-called personal factors.

b. Structural Factors

Structural factors that determine perceptions come from outside the individual, such as the environment, culture, laws, and values in society. They mostly affect a person in perceiving things.

Other factors that influence perception are basically divided into two: internal factors and external factors.

a. Internal factors that affect perception are the factors contained within the individual, which include the following areas :
a. Physiology
b. Attention
c. Interest
d. Similar needs
e. Experiences and memories
f. Mood

b. External factors that affect perception are the characteristics of the environment and the objects involved. External factors that influence the perception include:
a. Size and placement of an object or stimulus.
b. Color of the objects.
c. Peculiarity and contrast of the stimulus.
d. Intensity and strength of the stimulus.
e. Motion.

The instruments used to measure perceptions consist of four indicators adopted by Anu in [28] that have been modified, namely:

a. The amount of assets reported by a taxpayer is in accordance with the wealth obtained (the tax rate).

b. Implementation of fair tax sanctions.

c. Appropriate use of tax amnesty policy facilities.

d. Good service of tax officials. 


\section{Proposed Research Method}

This section presents the proposed hypothesis and research method.

\subsection{Hypotheses Development}

The Influence of Taxation Knowledge on Public Perception in the Implementation of Tax Amnesty Policy

This hypothesis tests the influence of taxation knowledge on public perception in the application of tax amnesty; the hypothesis proposed is as follows:

H1: Taxation knowledge significantly influences the public perception in the application of tax amnesty.

The Influence of Usability on Public Perception in the Implementation of Tax Amnesty Policy

This hypothesis tests the influence of usability on public perception in the application of tax amnesty, the hypothesis proposed is as follows:

H2: The usability significantly influences the public perception in the application of tax amnesty.

The Influence of Tax Penalties on Public Perception in the Implementation of Tax Amnesty Policy

This hypothesis tests the effect of taxation penalties on public perception in the application of tax amnesty, the hypothesis proposed is as follows:

H3: The tax penalties significantly influence the public perception in the application of tax amnesty.

The Influence of Taxation Knowledge, Usability, Tax Penalties on Public Perception in the Implementation of Tax Amnesty Policy

This hypothesis tests the effect of taxation knowledge, usability, and tax penalties on public perception in the application of tax amnesty, the hypothesis proposed is as follows: H4: The taxation knowledge, usability, and tax penalties significantly influence the public perception in the application of tax amnesty. 
From the hypotheses formulated above, the research framework can be described in Figure 2 as follows:

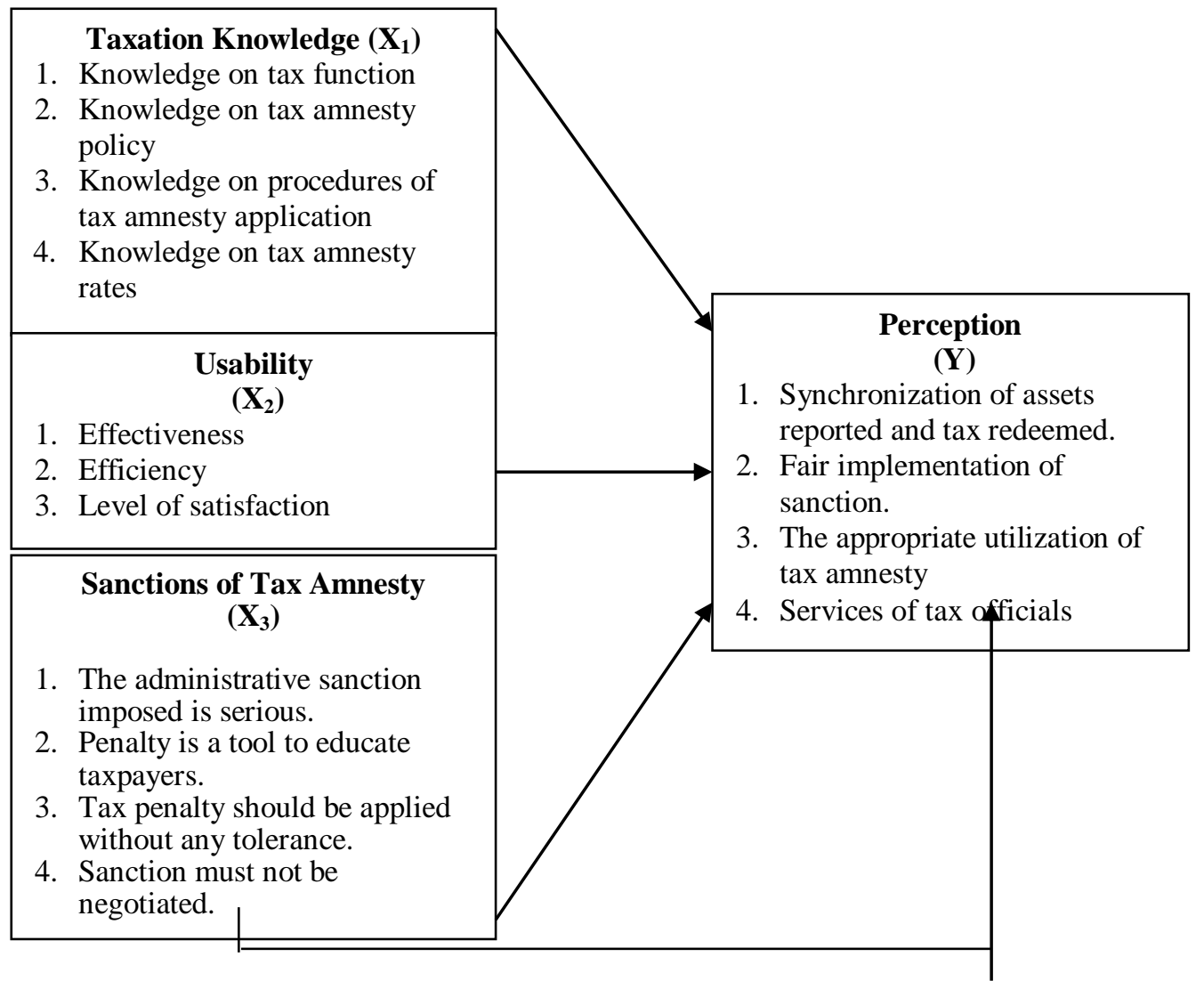

Figure 2. Framework of the Proposed Research

Based on the hypotheses in Figure 2 above, the objectives need to achieve in the preparation of this research are:

a. Testing and obtaining empirical evidence on the influence of taxation knowledge on public perception in the implementation of tax amnesty policy.

b. Testing and obtaining empirical evidence on the influence of tax usability on public perception in the implementation of tax amnesty policy.

c. Testing and obtaining empirical evidence on the influence of tax penalties on public perception in the implementation of tax amnesty policy.

d. Testing and obtaining empirical evidence on the influences of taxation knowledge, usability, and tax penalties on public perception in the implementation of tax amnesty policy.

\subsection{Research Model, Population, Sample, and Sampling Technique}

This study used quantitative research method with associative relationship with data collection from a survey. The population in this study was totaled 3,381 consisting of active taxpayers who pay taxes in the area of Kademangan Village, South Tangerang, Indonesia. Samples used in this study were amounted to 97.12 of respondents, but to simplify the study, the amount of samples was set at 100 respondents (rounding). Thus, questionnaires distributed were as many as 100 questionnaires for active taxpayers who pay taxes in the Kademangan Village, South Tangerang, Indonesia as the sample of respondents in this study. The sampling technique used in this study is non-probability sampling with accidental sampling technique (convenience sampling) [29]. 


\subsection{Research Variables}

The variables used in this study consist of two variables:

a. Independent Variables used in this study:

1) Taxation Knowledge

2) Usability

3) Sanction of tax amnesty

b. Dependent Variables used in this study are the taxpayers' perceptions in the implementation of tax amnesty policy.

\subsection{Technical Analysis}

Research data will be analyzed using SPSS 22. The analysis consists of: descriptive statistic, data quality testing; reliability test and validity test, classical assumptions test, and hypotheses test with multiple regression equation as follows:

where

$$
Y=\alpha+\beta_{1} x_{1}+\beta_{2} x_{2}+\beta_{3} x_{3}+e,
$$

$$
\begin{aligned}
& Y=\text { Perception } \\
& \alpha=\text { Constant } \\
& \beta=\text { Regression Coefficient } \\
& \mathrm{X}_{1}=\text { Taxation Knowledge } \\
& \mathrm{X}_{2}=\text { Usability } \\
& \mathrm{X}_{3}=\text { Tax Penalty } \\
& e \quad=\text { Error }
\end{aligned}
$$

\section{Results and Discussion}

This section presents the main results and following by discussion.

\subsection{Respondent Description}

Number of questionnaires distributed was as many as 100 respondents consisting of 48 male respondents (48\%), and 52 female respondents $(52 \%)$. Based on the term having a Taxpayer Identification Number (NPWP), there were 11 respondents $(11 \%)$ holding an NPWP $<1$ year, 69 respondents $(69 \%) 1-5$ years, 20 respondents ( $20 \%)$ holding an NPWP $>5$ years.

\subsection{Data Quality Test}

The data quality tests include the reliability test and validity test using SPSS Ver.22. Reliability test was performed with Cronbach's Alpha test, in which the value was greater than 0.60 and the validity test refers to correlated item-total correlation of $r$ table product moment with 5\% significance. The result of the reliability test uses Cronbach's Alpha. All measuring tools of dependent variables in this study consisted of average variables; average value accounting subjects as well as the independent variables consisting of behavioral learning, emotional intelligence and thinking ability had the value of Cronbach's Alpha bigger than 0.60. This indicates that the measuring instruments used in this study are reliable. Meanwhile, the validity of the results shows all values of $r$ is bigger than the value of $r$ table product moment at a significance level of $5 \%$ for the $n$ $=100$ is 0.755 . Therefore, it can be concluded that all of the mentioned items used as the measuring tools in this study are valid. 


\subsection{Classical Assumption Test}

Classical assumption test carried out in this study is the normality test using graph analysis (Normal Probability Plot) and Kolmogorov Smirnov test against dependent variables, entirely distributed normally. The multi-co-linearity test results on the independent variables with tolerance value showing that there is no independent variable that has tolerance less than 0.10 (VIF under 10), which means there is no correlation between the independent variables whose value is more than $95 \%$ or all of the independent variables are not found multi-co-linear. While the hetero-cedastisity results with Park test indicate a significance probability value above $5 \%$ of confidence level, or the significance of the correlation value is bigger than 0.05. It means the regression model used does not contain hetero-scedasticity. Hetero-scedasticity test results using plot scatter chart analysis indicate there is no clear pattern, and the dots are randomly spreading out on both, above and below 0 on the $y$ axis, it can be concluded that there is no hetero-cedastisity in the regression model, so that the regression model is declared appropriate to be used.

\subsection{The Influence of Taxation Knowledge on Public Perception in the Implementation of Tax Amnesty Policy}

The analysis result on the variable of taxation knowledge measured by the knowledge of taxpayer concerning the tax function has positive influence and significance on the perception of the taxpayer. This is because the wider insight and knowledge of the taxpayer on the tax function will influence the perception of the taxpayer. The analysis of the variable of taxation knowledge measured by taxpayer's knowledge on tax amnesty policy generates positive and significant effect on the perception of the taxpayer. This is due to the increasing level of information obtained that makes taxpayers aware of the tax amnesty policy. Moreover, the benefits of the program provided both for the state and the taxpayer then would affect better perception of the taxpayers. The analysis of the variable of taxation knowledge measured by taxpayer's knowledge on tax amnesty application procedures generates positive influence and significance effect on the perception of the taxpayer. This is because the information regarding the tax amnesty application procedures is easily obtained and will affect the perception of taxpayer regarding the easy procedure of filing a tax amnesty program.

The analysis of the variable of taxation knowledge measured by taxpayer's knowledge on the tax amnesty rate has positive and significant effect on the perception of the taxpayer. This is because the taxpayer insight and the rates prevailing in the application of tax amnesty policy are matched with the asset owned by the taxpayer, therefore, this affects the perception of taxpayer to fulfill his tax obligation. Then, generally, regarding the variable of taxation knowledge, it can be concluded that the deeper knowledge of the taxpayer will increase the perception of the taxpayer on tax amnesty policy. This is because the level of insight and knowledge of the taxpayer regarding tax amnesty policy implementation will determine the perception of the taxpayer.

\subsection{The Influence of Usability on Public Perception in the Implementation of Tax Amnesty Policy}

The analysis of the variable of usability measured by the effectiveness has positive and significant effect on the perception of the taxpayer. This is because the effectiveness of tax amnesty program for taxpayers in reporting the assets and payment of a ransom of assets reported will affect the perception of the taxpayer on tax amnesty policy. The analysis of the variable of usability, as measured by the efficiency has positive and significant effect on the perception of the taxpayer. This is because the efficiency of tax amnesty program that can save the tax cost of taxpayers to make up the reported wealth will affect the perception of the taxpayer against the tax amnesty policy. The analysis of 
the variable of usability measured by the level of satisfaction generates positive and significant effect on the perception of the taxpayer. This is because the taxpayer is satisfied and proud to be able to apply the tax amnesty program effectively and efficiently so as to affect the perception of the taxpayer on tax amnesty policy. Thus, generally, on the variable of usability, it can be concluded that the higher level of usability understanding on tax amnesty policy implementation of the taxpayer the more significant the perception of taxpayers regarding tax amnesty policy. This is because the level of insight and knowledge of the taxpayer regarding the usability of the application of tax amnesty policy will determine the perception of the taxpayer.

\subsection{The Influence of Tax Penalties on Public Perception in the Implementation of Tax Amnesty Policy}

The result of the analysis proves that the sanction of tax amnesty measured by serious administrative penalties imposed on violators of tax laws has positive and significant effect on the perception of the taxpayer in the region of Kademangan Village, South Tangerang, Indonesia. Since for taxpayer who does not cooperate in applying tax amnesty policy, the fines imposed is very high according to the violation that has been done. This will affect the perception of taxpayers on tax amnesty policy. The analysis result confirms that the sanction of tax amnesty, measured by the imposition of serious administrative penalties as one means of educating the taxpayer, has a significant positive effect on the perception of the taxpayer in the region of Kademangan Village, South Tangerang, Indonesia. This is because the sanction is another way to educate the taxpayers to be discipline in fulfilling their tax obligations and providing a deterrent effect to offenders. This will also affect the perception of the taxpayer on the tax amnesty policy. The result of the analysis confirms that the sanction of tax amnesty, measured by the imposition of tax penalties without tolerance, has positive and significant effect on the perception of the taxpayer in the region of Kademangan Village, South Tangerang, Indonesia. This is because the tax offenders will get administrative sanctions in accordance with the rules and regulations without giving any tolerance. This will affect the perception of the taxpayer on the application of tax amnesty policy. The results of the analysis shows that the sanction of tax amnesty measured by the imposition of sanction for tax offenders that is not negotiable has positive and significant effect on the perception of the taxpayer in the region of Kademangan Village, South Tangerang, Indonesia. This is because the imposition of strict sanctions for tax offenders that cannot be negotiated will influence the perception of taxpayers in the application of tax amnesty policy.

\subsection{The Influence of Taxation Knowledge, Usability, Tax Penalties on Public Perception in the Implementation of Tax Amnesty Policy}

Based on the results of the hypothesis testing, the effect of taxation knowledge, usability, and the sanctions of tax amnesty simultaneously give positive and significant impacts on the perception of taxpayers listed in the Pratama Serpong tax office (KPP), Kademangan area, South Tangerang, Indonesia. Eleven sub-variables of three independent variables - measured with the knowledge on tax function, tax amnesty policy, tax amnesty application procedures, tax amnesty rates, effectiveness, efficiency, degree of satisfaction, serious administrative sanctions, imposition of sanctions as a means of educating the taxpayers, the zero tolerance of sanctions and the imposition of sanctions that cannot be negotiated-can altogether and significantly influence the perception of taxpayers listed in KPP Pratama Serpong, Kademangan Village, South Tangerang, Indonesia. Thus, in order to create a good perception on the implementation of the tax amnesty policy for the taxpayers listed in KPP Pratama Serpong, registered in Kademangan Village, South Tangerang, Indonesia, the government should increase the level of knowledge of the taxpayers regarding the understanding of the tax amnesty, as 
well as improve their understanding of the usability of tax amnesty policy and tax amnesty sanctions to crack down the violators of tax regulations. This study is in line with the research conducted by Anggraeni in [30], finding that the sunset policy program had a positive influence on the consciousness of paying taxes, knowledge and understanding on the tax rules, and a good perception on the effectiveness of the tax system. In addition, this study is also parallel with the research conducted by Susanti in [31] showing a significant difference between the sunset policy towards consciousness of paying taxes, the sunset policy towards understanding the tax laws and the sunset policy towards a good perception on the system's effectiveness.

\section{Conclusion}

The conclusion of the study on the effect of taxation knowledge, usability, tax penalty, and public perception on the application of tax amnesty is that the taxation knowledge measured by knowledge of the taxpayer on tax functions, tax amnesty policy, tax amnesty application procedures, and the tax amnesty rates, has positive and significant effect on the perception of the taxpayer in the tax amnesty policy implementation. The variable of usability measured by the effectiveness, efficiency, and satisfaction level on the tax amnesty rates has positive and significant effect on the perception of the taxpayer in the implementation of tax amnesty policy. Likewise, the variable of tax amnesty penalty measured by the serious administrative penalties imposed on violators of tax laws as a method of educating the taxpayers, as well as the tax penalty that should be imposed on violators without tolerance and negotiation, has significant effect on the perception of the taxpayers in the tax amnesty policy implementation in Kademangan Village.

\section{Acknowledgement}

This research is supported by Universitas Teknologi Yogyakarta, Indonesia. The authors would like to express gratitude to William Christian Samuel for finalizing this manuscript.

\section{References}

[1] Mardiasmo, Perpajakan Edisi Revisi, Yogyakarta: penerbit Andi, (2011).

[2] Fidel, Pembahasan UU No. 36 Tahun 2008 tentang Pajak Penghasilan, Jakarta: Carofin Publishing, (2008).

[3] T. V. Rantum and H. A. Priyono, "Dampak 'Sunset Policy' terhadap Faktor-faktor yang Mempengaruhi Kemauan Membayar Pajak, Simposium Nasional Perpajakan II, (2009).

[4] Mardiasmo, Perpajakan Edisi Revisi, Yogyakarta: penerbit Andi, (2013).

[5] I. Y. Anggraeni and N. F. Saryadi, "Faktor-faktor yang mempengaruhi kepatuhan wajib pajak terhadap penerimaan pajak penghasilan pada kantor pelayanan pajak pratama semarang tengah satu", Diponegoro Journal of Social and Politic, (2013), pp. 1-11.

[6] The Republic of Indonesia, Law No. 11 of 2016 on Tax Amnesty, (2016).

[7] Ritsema, "Economic and Behavioral Determinants of Tax Compliance: Evidence from the 1997 Arkansas Tax Penalty Amnesty Program”, In IRS research Conference, (2003).

[8] S. H. Luitel and S. R. Sobel, "The Revenue Impact of Repeated Tax Amnesties", Public budgeting \& finance, vol. 27, no. 3, (2005), pp. 19-38.

[9] The Republic of Indonesia. Law No. 28 of 2007 General Provisions and Taxation Procedures.

[10] Mardiasmo, "Pengetahuan Perpajakan", Yogyakarta: Penerbit Andi, (2016).

[11] S. Soemahamidjaja, "Pajak Berdasarkan Azas Gotong Royong", Universitas Padjadjaran, Bandung, (1964).

[12] W. B. I. Waluyo and W. Ilyas, Perpajakan Indonesia, Cetakan Terbaru, Jakarta, Salemba Empat, (2003).

[13] The Ministry of Finance, Minister of Finance Regulation No.118/PMK.03/2016 on Tax Amnesty.

[14] S. Notoatmodjo, Metodologi Penelitian Kesehatan, Jakarta: Rineka Cipta, (2010).

[15] Indonesian Dictionary, "Kamus Besar Bahasa Indonesia on the Definition of Knowledge, (2012).

[16] Veronica Carolina, Pengetahuan Pajak, (2009).

[15] S. R. Rahayu, "Perpajakan Indonesia: Konsep dan Aspek Formal”, Yogyakarta: Graha Ilmu, (2010). 
[17] Imaniyah and B. D. Handayani, "Pengaruh Penghasilan dan Pengetahuan Perpajakan terhadap Kepatuhan Wajib Pajak dalam Membayar Pajak Bumi dan Bangunan (PBB) di Kelurahan Tegalrejo Kota Pekalongan", Universitas Dipoinegoro, Semarang, (2008).

[19] International Organization for Standardization, "Pengertian dan Faktor-Faktor Yang Mempengaruhi Daya Guna", (1998).

[20] N. K. Muliari and P. E. Setiawan, "Pengaruh Persepsi tentang Sanksi Perpajakan dan Kesadaran Wajib Pajak pada Kepatuhan Pelaporan Wajib Pajak Orang Pribadi di Kantor Pelayanan Pajak Pratama Denpasar Timur", Jurnal Ilmiah Akuntansi dan Bisnis, vol. 6, no. 1, (2010).

[21] S. Resmi, "Perjakan Teori dan Kasus Edisi 4", Jakarta: Salemba Empat, (2008).

[22] Z. Choiriyatus, "Pengaruh Tingkat Pemahaman, Kepatuhan dan Ketegasan Sanksi Perpajakan terhadap Kewajiban Perpajakan Pengusaha Usaha Kecil dan Menengah (UKM) di Wilayah Jakarta Selatan", Undergraduate Thesis. Jakarta: Faculty of Economic and Social Sciences, Universitas Islam Negeri Syarif Hidayatullah, (2010).

[23] I. K. Yadnyana, "Pengaruh Moral dan Sikap Wajib Pajak pada Kepatuhan Wajib Pajak Koperasi di Kota Denpasar", Denpasar: Faculty of Economics, Universitas Udayana, (2009).

[24] J. Rakhmat, "Psikologi Komunikasi”, Bandung: Remaja Rosdakarya, (2011).

[25] B. Walgito, "Pengantar Psikologi Umum”, Yogyakarta: Andi Offset, (2002).

[26] H. J. Leavitt, "Managerial Psychology in Alex Sobur 2009 'Psikologi Umum”, Bandung: CV Pustaka Setia, (1978).

[27] D. Mulyana, "Ilmu Komunikasi Suatu Pengantar", Bandung: Remaja Rosdakarya, (2005).

[28] A. Anu, "Pengaruh Persepsi Wajib Pajak Bumi dan Bangunan terhadap Kepatuhan Wajib Pajak di Kota Salatiga", Salatiga: Faculty of Economics, Universitas Kristen Setya Wacana, (2004).

[29] Sugiyono, "Metode Penelitian Kuantitatif, Kualitatif dan R\&D”, Bandung: Alfabeta, (2012).

[30] M. D. Anggraeni, "Pengaruh Pemanfaatan Fasilitas Perpajakan Sunset Policy terhadap Tingkat Kepatuhan Wajib Pajak", Faculty of Economics, Universitas Diponegoro Semarang, (2011).

[31] C. Susanti, "Pengaruh Kebijakan Sunset Policy terhadap Faktor-Faktor yang Mempengaruhi Kemauan Membayar Pajak", Faculty of Economics, Universitas Jember, (2011). 
International Journal of $u-$ and e- Service, Science and Technology Vol.10, No.4 (2017) 